\title{
Benveniste e Agamben: o ético e o político na linguagem revelados pela blasfemia e pelo juramento
}

\author{
Elisa Marchioro Stumpf ${ }^{1}$ \\ Universidade Federal de Pelotas, Pelotas, RS, Brasil
}

Resumo: O artigo analisa a contribuição do linguista Émile Benveniste e do filósofo Giorgio Agamben sobre os temas blasfemia e juramento, a fim de discutir suas implicações no tratamento do aspecto ético e político do exercício da fala. De Benveniste, estudam-se os textos "A blasfemia e a eufemia" e suas publicações sobre o juramento na Grécia e em Roma, que são cotejados com "O sacramento da linguagem: uma arqueologia do juramento", de Agamben. Conclui-se que o juramento e a blasfemia são vestígios de uma experiência performativa da linguagem em que havia plena correspondência entre as palavras, as ações e o mundo e, como tais, são fenômenos privilegiados para revelar como o homem, ao enunciar para assumir-se enquanto sujeito, torna-se responsável por aquilo que fala.

Palavras-chave: Blasfemia; Juramento; Émile Benveniste; Giorgio Agamben.

Title: Benveniste and Agamben: the ethical and the political within language revealed through blasphémie and oath

Abstract: The article analyzes the contributions of the linguist Émile Benveniste and the philosopher Giorgio Agamben about blasphémie and oaths in order to discuss the implications for dealing with ethical and political aspects of speech. Benveniste's text "La blasphémie et l'euphémie" and his publications about oaths in Rome and Greece are studied and examined along with Agamben's The Sacrament of Language: An Archaeology of the Oath. The text concludes that blasphémie and oaths are remnants of a performative language experience in which there was full correspondence among words, actions and the world. As such, they are privileged phenomena to reveal how men, by enunciating and becoming a subject, becomes also responsible for what they speak.

Keywords: Blasphémie; Oaths; Émile Benveniste; Giorgio Agamben.

\section{Introdução}

Este artigo ${ }^{2}$ foi apresentado no III Colóquio Leituras de Émile Benveniste, realizado na Universidade Federal de Pelotas em outubro de 2019, no eixo que se propunha a discutir os

\footnotetext{
${ }^{1}$ Doutora em Letras - Análises Textuais, Discursivas e Enunciativas - pela Universidade Federal do Rio Grande do Sul. Professora adjunta de português como língua adicional na Universidade Federal de Pelotas. Orcid: https://orcid.org/0000-0002-9080-0903. E-mail: elisa.stumpf@gmail.com.

${ }^{2} \mathrm{O}$ texto que segue retoma e expande reflexões realizadas em nossa tese de doutorado, intitulada "No limite do diálogo: eufemismo e enunciação em Émile Benveniste" (STUMPF, 2017), realizada sob a orientação do professor dr. Valdir do Nascimento Flores.
} 
efeitos da teoria da linguagem de Benveniste na reflexão de campos e autores conexos. 0 autor escolhido para dialogar com Benveniste foi o filósofo italiano Giorgio Agamben. Não é surpresa, para os conhecedores da sua obra, as inúmeras passagens em que o filósofo recorre às reflexões de Benveniste para sustentar suas proposições sobre a linguagem e o ser humano. Embora mereça ser estudado mais detalhadamente, parece-nos que o recurso ao linguista não é nem esporádico nem acessório, pois diz respeito a problemáticas fundamentais da obra de Agamben, tais como a linguagem e a politicidade (CASTRO, 2013), do qual nos ocuparemos neste texto.

Nossa proposta, neste texto, não é exatamente constatar os efeitos da teoria da linguagem benvenistiana em Agamben, antes pelo contrário: o que apresentamos é mais um efeito da leitura de Agamben na teorização que desenvolvemos a partir da obra de Benveniste. Cabe ressaltar que tratamos de algo específico: nosso recurso ao filósofo circunscreve-se à obra intitulada "O sacramento da linguagem: arqueologia do juramento" (2011). Ao discorrer sobre o juramento, Agamben necessariamente passa pelos estudos de Benveniste sobre tal fenômeno nos mundos grego e romano, ainda que tais exposições sejam alvos de críticas por parte do filósofo. Além disso, o autor trata da proximidade do juramento com a blasfemia e finaliza sua obra ampliando sua reflexão sobre a linguagem e o seu papel no mundo a partir de Benveniste.

É no encontro entre blasfemia e juramento e as consequências para se pensar a atividade de linguagem no seio da sociedade que nosso trabalho se situa. Mais especificamente, buscamos traçar o raciocínio que leva da blasfemia ao juramento, do linguista ao filósofo, para elaborar nossa reflexão sobre o exercício da linguagem pelos homens na sociedade. Iniciamos com uma análise do texto "A blasfemia e a eufemia" (BENVENISTE, 2006[1969]), amparada pelas explicações de Ono (2012) sobre as notas preparatórias a esse texto. Este texto leva-nos às entradas do Vocabulário das instituições indo-europeias (BENVENISTE, 1995) sobre juramento na Grécia e em Roma e ao artigo "L'expression du serment dans la Grèce ancienne" (BENVENISTE, 1947). Posteriormente, passamos às reflexões de Agamben sobre o juramento, situando a crítica deste a Benveniste e mostrando o impacto da sua leitura em nossa elaboração. Por fim, discutimos as implicações depreendidas do diálogo entre os autores sobre o homem, as palavras e o mundo.

\section{"A blasfemia e a eufemia"}

O texto intitulado "A blasfemia e a eufemia" foi publicado nas atas de um colóquio voltado para a linguagem teológica ("L'analise du langage théologique: le nom de Dieu"), ocorrido em Roma, em janeiro de 1969. Embora seja breve, é bastante denso e complexo. De acordo com Ono, no seu estudo das notas preparatórias desse texto, "as ideias expostas se situam no cruzamento de várias problemáticas interessantes e podem fornecer um rico 
material para nossa reflexão sobre alguns conceitos-chave da linguística benvenistiana" 3 (2012, p. 77).

É importante iniciar com uma explicação a respeito do próprio assunto do texto. De acordo com o dicionário Larousse, blasphème é definido como "fala ou discurso que ultraja a divindade, a religião ou aquilo que é considerado como respeitável ou sagrado"4. À primeira vista, esse vocábulo parece dizer respeito apenas ao domínio da religião, visto que muitas religiões consideram o ato de blasfemar como algo condenável. Entretanto, também é verdade que isso ocorre em muitas sociedades. Para Levy (1993), a blasfêmia é um crime passível de punição até mesmo na esfera civil, pois se considera que tolerá-la equivale a aprová-la. Isso poderia servir como um convite para que se faça o mesmo, colocando em perigo a unidade da sociedade, na medida em que a blasfêmia questiona uma crença coletiva ${ }^{5}$. Freud também afirma que a violação de um tabu é um perigo social, cuja punição deve recair sobre todos os membros da sociedade, para que evitem ser prejudicados. Além disso, para o autor, "se os outros não punissem a violação, necessariamente se dariam conta de que querem fazer o mesmo que o transgressor" (FREUD, 2013, p. 77). Na França, o delito da blasfêmia, introduzido nas leis no século XIII, foi delas retirado apenas em 1881, com a instauração da liberdade de imprensa (LESAFFRE, 2012). A análise do artigo "A blasfemia e a eufemia" deixa entrever a importância desse tópico, do qual Benveniste irá reter um aspecto - a própria pronúncia do nome de Deus 6 .

Iniciamos a discussão esclarecendo o vocabulário empregado por Benveniste. No início do texto, o linguista explica a terminologia empregada, afirmando que os termos "blasfemia" e "eufemia" são neologismos motivados por duas questões. Em primeiro lugar, não se pode confundir "blasfemia" com "blasfêmia". Para o autor, esta última é definida como "asserção difamante relativamente à religião ou à divindade" (BENVENISTE, 2006, p. 259). Em outras palavras, blasfêmia é uma fala considerada ultrajante que envolve o âmbito religioso. A blasfemia, por sua vez, é definida como "um processo de fala ... [que] consiste, de uma certa

\footnotetext{
${ }^{3}$ Do original: "les idées qu'il expose se situent au croisement de plusieurs problématiques intéressantes et peuvent fournir de riches matières à notre refléxion sur certains concepts clefs de la linguistique benvenistienne". Tradução de nossa responsabilidade, bem como as demais presentes neste artigo.

${ }^{4}$ Do original: "parole ou discours qui outrage la divinité, la religion ou ce qui est considéré comme respectable ou sacré".

${ }^{5}$ Leveleux-Teixeira (2008) mostra a dificuldade de dar conta da blasfêmia em diversos discursos - moral, normativo, judiciário, religioso etc. - e o descompasso entre as denúncias e as punições, que "testemunham a complexidade e a plasticidade do crime da blasfêmia: mesmo após sua consideração pelo direito, uma larga margem de incertidão hermenêutica sempre persistiu na sua apreensão: 'crime sem vítima' e, portanto, altamente simbólico, a blasfêmia foi, por excelência, o objeto de interpretações contraditórias" (2008, p. 31-32). Do original: "témoignent de la complexité et de la plasticité du crime de blasphème: même après sa prise en charge par le droit, une grande marge d'incertitude herméneutique persista toujours dans son appréhension: 'crime sans victime' et donc crime hautement symbolique, le blasphème fut, par excellence l'objet d'interprétations contradictoires".

${ }^{6} \mathrm{O}$ que se entende por blasfêmia mudou ao longo dos séculos e de acordo com diferentes religiões. Segundo Levy (1993), a tradição judaica proíbe a pronúncia do nome de Deus, considerando seu emprego na fala como blasfêmia. A ideia de que blasfêmia está relacionada com uma ofensa relacionada a Deus ou ao sagrado surge com o cristianismo ao ponto de Clemente II considerar como blasfêmia tudo o que violava a autoridade eclesiástica (LEVY, 1993, p. 35).
} 
maneira, em substituir o nome de Deus por sua injúria" (BENVENISTE, 2006, p. 260). Se a primeira função do neologismo "blasfemia" serve para distingui-lo do termo já existente "blasfêmia", a segunda função está relacionada com o outro termo introduzido pelo autor: a eufemia. Há dois motivos para isso: associar os dois termos, que não costumam ser estudados de forma conjunta, e propô-los como atividades simétricas.

Para Benveniste, blasfemia e eufemia são atividades correspondentes, mas que se dão em forças opostas. Seu resultado é a imprecação, definida como "expressão blasfêmica por excelência" (2006, p. 259). É importante notar como, para o linguista, esse fenômeno pertence ao domínio da linguagem, embora seu estudo seja geralmente relegado ao léxico e à fraseologia, visto que os linguistas não sabem como lidar com tais expressões típicas. Nas notas preparatórias, observamos Benveniste questionando a linguística da época, pois, no escopo da linguística que se intitula "moderna", esse tipo de questão não é contemplado; entretanto, "a linguística não pode negligenciar o homem na língua"7 (ONO, 2012, p. 79). Assim, a linguística idealizada por Benveniste deve, sim, tratar das diversas relações estabelecidas entre homem e linguagem e, dessa forma, contemplar fenômenos considerados "marginais", tais como a blasfemia ${ }^{8}$.

Considerando que os estudos da linguagem, por muito tempo, tiveram um caráter prescritivo e foram vistos como uma forma de regular o que significa "falar bem", percebemos que, incluir, na linguística, a blasfemia e outros fenômenos que dizem respeito à expressão das emoções envolve se deparar com uma contestação das leis fundamentais da língua, com uma espécie de "anti-gramática" que iria de encontro a uma linguística preocupada em estabelecer regras de bom uso da língua (ONO, 2012, p. 79). Aqui encontra-se uma justificativa para a exclusão desse tópico dos estudos sobre a linguagem, o que acontece até os dias de hoje ${ }^{9}$.

Embora pertencentes ao domínio da linguagem, as notas preparatórias do texto deixam entrever como Benveniste acreditava que o estudo de tais fenômenos deveria envolver várias outras disciplinas, como religião, literatura e psicanálise. Prova disso é, para Ono (2012, p. 77), a presença de diferentes autores pertencentes a tais domínios nas notas. Entretanto, nos estudos linguísticos, "não se retém da imprecação senão os aspectos pitorescos, anedóticos, sem prender-se à motivação profunda nem às formas específicas da expressão" (BENVENISTE, 2006, p. 259). No texto em questão, é exatamente o que Benveniste faz: explicar as causas da blasfemia e seu quadro locucional, ou seja, como e em que circunstâncias ela se manifesta no discurso. Iniciamos nossa exposição, portanto, com as suas causas.

\footnotetext{
7 Do original: "la linguistique ne doit pas négliger l'homme dans la langue".

${ }^{8}$ Orsi (2011, p. 345), em estudo sobre a lexia obscena, corrobora essa constatação, afirmando que é um tema "ainda menosprezado por linguistas", sendo "quase nula a referência aos palavrões em obras lexicológicas e lexicográficas", apesar da riqueza que este recorte lexical oferece aos linguistas.

${ }^{9}$ Encontramos um testemunho em Preti (1983, p. 3, grifos nossos), quando o autor afirma que "o estudo da linguagem erótica, como não poderia deixar de ser, situa-se no campo dos tabus linguísticos morais e abrange áreas sobre as quais, quase sempre e por motivos óbvios, se tem preferido calar, como, por exemplo a dos vocábulos obscenos, a dos 'palavrões' e blasfêmias, a da gíria, a do discurso malicioso".
} 


\section{Da motivação}

Segundo o autor, nas línguas ocidentais, a blasfemia e suas diversas manifestações linguísticas provêm da "necessidade de violar a interdição bíblica de pronunciar o nome de Deus ${ }^{10 "}$ (BENVENISTE, 2006, p. 260). Essa proibição não diz respeito a falar sobre Deus, mas, sim, de pronunciar o seu próprio nome. Isso resulta na supressão dessa palavra do repertório linguístico, o que constituiria um paradoxo próprio dos tabus: "este nome deve ao mesmo tempo continuar a existir enquanto 'interdito'” (BENVENISTE, 2006, p. 260). Há outras evidências que colocam a pronúncia do nome de Deus como o interdito máximo. Em primeiro lugar, as consequências negativas ${ }^{11}$ que a acompanham. Em segundo lugar, a interdição sobre a pronúncia do nome de Deus é observada até mesmo em sociedades que ignoram quando esse tabu diz respeito à pronúncia do nome dos mortos ${ }^{12}$. Isso vem da crença segundo a qual a simples pronúncia de tais nomes poderia fazer o morto voltar ao mundo dos vivos (ONO, 2012, p. 84). Essas duas interdições são orientadas pelo mesmo princípio: a identificação entre falar e existir. Ou seja, pronunciar um nome seria invocar e provocar a existência deste ser no mundo.

Aparece, neste momento o único recurso a um autor fora da linguística: Benveniste utiliza as reflexões de Freud para explicar a natureza dos tabus. De acordo com o psicanalista, o tabu seria uma proibição antiga contra os desejos mais fortes do homem, determinada por alguma autoridade exterior. Ao profundo desejo humano de profanar o sagrado, sobrepõe-se o interdito do nome de Deus, visto que

[...] a tradição religiosa não quis reter senão o sagrado divino e excluir o sagrado maldito. A blasfemia, à sua maneira, pretende restabelecer essa totalidade, profanando o próprio nome de Deus. Blasfema-se o nome de Deus, pois tudo o que se possui de Deus é o seu nome. É só por aí que se pode atingi-lo, para comovê-lo ou para feri-lo: pronunciando seu nome (BENVENISTE, 2006, p. 260, grifos do autor).

Temos também um paralelo entre o juramento e a blasfemia, pois o único momento em que o nome de Deus é invocado fora do culto é o juramento. Para Benveniste (2006), Deus, como testemunha máxima da verdade, faz-se presente no juramento, visto que esse é um apelo a Deus, e aquele que jura está sujeita ao castigo divino em caso de perjúrio. A blasfemia

\footnotetext{
${ }^{10}$ Ono (2012) afirma que, aqui, se encontra um dos vestígios do judaísmo na obra de Benveniste, uma questão de pesquisa que está por ser explorada.

${ }^{11}$ Benveniste não especifica quais seriam as punições, mas a tradição judaico-cristã previa diferentes castigos corporais para quem pronunciasse o nome de Deus (LEVY, 1993). Na esfera civil, Nash (2007) mostra como as leis contra blasfêmia estabeleceram diferentes tipos de penas na sociedade francesa entre os séculos XIV e XVII, desde mutilações até mesmo a morte.

12 Freud mostra como isso ocorre em diversos povos e afirma que "a evitação do nome do falecido geralmente é aplicada com um rigor extraordinário" (2013, p. 103). Além disso, de acordo com o autor, "para os selvagens o nome é uma parte essencial e um patrimônio importante da personalidade de que eles atribuem à palavra um pleno significado de coisa" (FREUD, 2013, p. 104). O nome se identifica ao ser, portanto "pronunciar seu nome Ihes parece uma invocação à qual se seguirá de imediato sua presença” (FREUD, 2013, p. 106). Decorrem disso inúmeras tentativas de modificar o nome para que ele não seja proferido.
} 
também traz o nome de Deus, tomando-o como testemunha, uma vez que ela funciona como um juramento de ultraje.

De acordo com Ono (2012), a questão do juramento e sua relação com a blasfemia encontram-se mais presentes nas notas preparatórias do que no texto final. Além disso, o juramento é tema de três estudos de Benveniste ${ }^{13}$, o que atesta sua importância para sua teorização sobre a linguagem. Na língua francesa, constatamos a proximidade desses atos no paralelismo entre o substantivo juron ("imprecação") e o verbo jurer (“jurar"). Blasfemia e juramento encontram-se unidos por duas características. Em primeiro lugar, ambos são performativos. No caso do juramento, pode-se afirmar isso visto que ele dá testemunho daquilo que está sendo jurado. Em segundo lugar, ambos apresentariam uma origem religiosa comum. Entretanto, os dois diferem no que diz respeito à atitude do locutor, pois enquanto o juramento é um "ato de crença" (acte de croyance), a blasfemia é o "escárnio" (dérision) de um ato de crença.

\section{Do quadro locucional}

Na explicação do quadro locucional da blasfemia, Benveniste destaca primeiramente a própria forma de expressão, o que requer falar do domínio da expressão emocional. Contrariamente ao que se poderia imaginar, tal campo tem suas regras e sintaxe próprias. De acordo com o autor, "a blasfemia se manifesta como exclamação, ela tem a sintaxe das interjeições, das quais constitui a variedade mais típica" (2006, p. 261, grifo do autor). Essa é uma característica fundamental, pois a "imprecação é bem uma palavra que se 'deixa escapar', sob a pressão de um sentimento brusco e violento". Segundo Ono (2012), essa característica ocupa um espaço maior nas notas preparatórias: "a nota do folio 348 do nosso arquivo chega mesmo a utilizar a imagem de um vulcão para descrever a imprecação como uma 'explosão', assinalando que é esta a sua 'natureza primeira'"14 $(2012$, p. 81, grifo da autora).

Diferentemente das interjeições onomatopeicas (oh!, ai! etc.), a blasfemia utiliza formas significantes. Embora tenham um sentido, elas não comunicam, mas somente expressam, pois não se referem a nenhuma situação particular. Por isso, pode-se pronunciar a mesma palavra em diferentes circunstâncias, pois ela exprime apenas a intensidade de uma reação a tais circunstâncias. Elas não declaram algo a respeito da situação, mas indicam a atitude do locutor em relação a esta. Ademais, elas não transmitem mensagem alguma nem dão abertura a um diálogo, visto que não se dirigem nem a um parceiro de interlocução (tu) cuja presença sequer é necessária - nem a uma terceira pessoa (ele). As imprecações tampouco descrevem aquele que as emite $(e u)$, pois "este se trai mais do que se revela"

\footnotetext{
${ }^{13}$ Referimo-nos aqui ao texto "L'expression du serment dans la Grèce ancienne" (1947) e às entradas intituladas "ius e juramento em Roma" e "O juramento na Grécia", presentes no Vocabulário das Instituições Indoeuropeias, volume II.

${ }^{14}$ Do original: "Ia note du folio 348 de notre dossier va d'ailleurs jusqu'à utiliser l'image du volcan pour décrire le juron comme une 'explosion', soulignant que c'est là son 'premier caractère'".
} 
(BENVENISTE, 2006, p. 261), o que mostra seu lado súbito e intempestivo.

Ainda que surjam de uma descarga emotiva, as imprecações são realizadas em fórmulas fixas. Benveniste explica que a forma de base é a exclamação "nome de Deus", costumeiramente reforçada com um epíteto que destaca a transgressão: "sagrado nome de Deus". "Deus" pode ainda ser substituído por alguma outra entidade religiosa, tal como "madona" ou "virgem". Pode-se também acentuar a imprecação ao utilizar, no lugar do "nome", o "corpo" ou algum órgão, ou ainda a sua "morte", reduplicando a expressão. Por fim, pode-se simplesmente invocar o nome do Diabo, o anti-Deus.

É por meio dessas formas que se pode transgredir uma interdição em um momento cuja intensidade leva o homem a invocar o nome de Deus. Contudo, Benveniste acrescenta que "esta exclamação suscita imediatamente uma censura" (2006, p. 262). A pronúncia da blasfemia é acompanhada de uma tentativa de modificá-la, o que o linguista chama de eufemia. Nela, mantém-se o quadro locucional da blasfemia, mas podem ser inseridos três tipos de modificações na expressão linguística. Em primeiro lugar, o nome de "Deus" pode ser substituído por outro termo qualquer. Em segundo lugar, pode-se mutilar a palavra "Deus", suprimindo a sílaba final ou substituindo-a por uma sílaba de mesma assonância. Em terceiro lugar, pode-se ainda criar uma forma nonsense no lugar da expressão blasfêmica.

Entende-se, assim, por que Benveniste propõe tratar a blasfemia e a eufemia de forma conjunta, pois são "atividades simétricas" que funcionam como "forças opostas". Nas palavras do linguista, "a blasfemia subsiste, mas é mascarada pela eufemia que lhe substrai a realidade fêmica, portanto sua eficácia sêmica, tornando-a literalmente destituída de sentido" (2006, p. 262). Dessa forma, a blasfemia não é realizada, embora continue fazendo uma alusão à profanação de linguagem. Assim, a palavra preenche a função psíquica e o desejo de transgredir o tabu, entretanto, é disfarçada pela eufemia.

Pode-se, agora, compreender a densidade dos temas abordados no texto. Além disso, sua data de publicação coloca-o como contemporâneo de "O aparelho formal da enunciação". Em ambos se faz presente a questão da enunciação. Ainda que não encontremos o termo "enunciação" no texto publicado, ele aparece de forma constante nas notas preparatórias, nas quais a blasfemia é entendida como um ato de enunciação (ONO, 2012, p. 78). Ono mostra como algumas notas de ambos os artigos caracterizam a blasfemia e a enunciação como atos repentinos e expressivos. Para a autora, de acordo com esse raciocínio, pode-se pensar que a linguagem é entendida como algo que surge do próprio ato de falar, de forma tão forte que ultrapassa o indivíduo.

Ademais, Ono discute o trecho "o nome de Deus não pode passar pela boca, pois o ato de pronunciar imprime um traço no mundo, e o nome é o $\operatorname{ser}^{\prime 15}(2012$, p. 83), comparando esse trecho com a caracterização que Benveniste faz da enunciação como algo evanescente, o que poderia parecer contraditório. Se toda a enunciação se apaga logo depois do seu proferimento, como entender a caracterização da blasfemia como algo que "imprime um

\footnotetext{
${ }^{15}$ Do original: "le nom de Dieu ne doit pas passer par la bouche, car l'acte de prononcer imprime une trace dans le monde, et le nom c'est l'être".
} 
traço no mundo"? De acordo com Ono, tal característica não se restringiria apenas à pronúncia do nome de Deus, já que toda enunciação imprimiria algo no mundo. Embora a enunciação se realize em uma instância de tempo e seja irrecuperável, ela age sobre o mundo e nele deixa seus traços. É pela palavra que a existência dos seres é assegurada - a começar pela nossa, enquanto sujeitos, visto que "é na linguagem e pela linguagem que o homem se constitui como sujeito" (BENVENISTE, 2005, p. 288). Dito de outro modo, ainda que a enunciação seja evanescente, ela cria algo no mundo através da palavra. Isso nos leva a pensar no peso que a enunciação tem, pois, uma vez que o homem fala, não se pode voltar atrás, raciocínio que nos conduz a uma consideração sobre os aspectos ético e político do exercício da fala, os quais estudaremos a partir da questão do juramento.

\section{O juramento}

Dada a menção do juramento no texto anterior, algo também apontado por Agamben, é necessário um exame mais detalhado dessa presença. Conforme havíamos afirmado, há três artigos de Benveniste que versam sobre a questão do juramento e sua função nas sociedades grega e romana. Analisamos o texto "L'expression du serment dans la Grèce ancienne" (1947) e as entradas "ius e juramento em Roma" e "O juramento na Grécia", encontradas na seção intitulada "Direito", no segundo tomo do Vocabulário das Instituições Indo-europeias.

Começamos com uma observação presente nos três textos. Benveniste declara que não há uma expressão única para as palavras "jurar" e "juramento" em indo-europeu: "não existe termo indo-europeu que se possa considerar que esteja presente em todas as línguas antigas e que seja propriamente referente à tal noção" (BENVENISTE, 1995, p. 165). Esse achado pode parecer surpreendente quando se sabe da importância dessa instituição nas sociedades indo-europeias. O linguista explica essa ausência em função da própria natureza do juramento, que "não constitui uma instituição autônoma, não é um ato que tenha significação por si só e seja auto-suficiente” (BENVENISTE, 1995, p. 166).

De acordo com o linguista, o juramento

$$
\begin{aligned}
& \text { é uma modalidade particular de asserção, que sustenta, garante, demonstra, mas } \\
& \text { que não funda nada. Individual ou coletivo, o juramento não se dá senão por aquilo } \\
& \text { que ele reforça ou soleniza: pacto, engajamento, declaração. [...] Sua função consiste } \\
& \text { não na afirmação que ele produz, mas na relação que ele institui entre a fala } \\
& \text { pronunciada e o poder invocado (BENVENISTE, 1947, p. 82, grifos do autor). }
\end{aligned}
$$

Também pode-se constatar uma dissimetria em grego e em outras línguas (mas não em português) entre o verbo e o substantivo. Temos, em inglês, por exemplo, o verbo to swear e o substantivo oath. Em grego, o verbo é ómnumi e o substantitvo hórkos, sendo que ambas as palavras não são utilizadas para se falar senão do juramento. Dada a impossibilidade de esclarecer a significação desses termos no próprio grego, Benveniste parte para um estudo etimológico do verbo e afirma que seu radical pode ser aproximado de um verbo sânscrito cujo significado é "pegar" ou "apreender". Deve-se, assim, partir desse sentido e integrá-lo a 
uma explicação total da expressão.

Benveniste continua com o estudo de hórkos, visto que "na língua poética desde Homero, hórkos com ómnumi é a expressão pura e simples do 'juramento'” (1995, p. 168). Impossibilitado de recorrer à etimologia, resta ao linguista analisar seu emprego no grego. Para Benveniste, na língua homérica, hórkos é utilizado para designar qualquer espécie de juramento, sendo seu sentido independente da modalidade de juramento em questão. Porém, hórkos, nesse contexto não é empregado para se referir a um fato de fala, mas a um objeto. Assim, torna-se possível relacionar o substantivo hórkos e o verbo ómnumi: "daí a expressão 'segurar o hórkos': objeto ou matéria, esse hórkos é o objeto sacralizante que contém uma potência que pune qualquer falta à palavra dada (BENVENISTE, 1995, p. 170).

No próprio sentido de hórkos, haveria uma ideia de uma "substância carregada de malefícios, potência divina, autônoma, que castiga o perjúrio" (BENVENISTE, 1995, p. 170). Quando se associa ao juramento essa qualidade, ele aparece como uma operação de caráter condicional em caso de descumprimento. Ao constatar esse fenômeno em outras línguas, Benveniste (1995, p. 170) propõe a seguinte explicação: "quem jura se expõe à maldição em caso de perjúrio, e ele soleniza seu ato tocando o objeto ou a substância investida desse terrível poder".

Confirma-se essa interpretação ao analisarmos o termo epíorkos, que significa "perjuro", e do verbo epiorkeîn, "perjurar". Para explicá-los, Benveniste mostra que é

por meio de uma ligação implícita entre o juramento proferido e a palavra mentirosa que ele defende. A idéia, portanto, é de acrescentar (epi) um juramento (hórkos) a uma palavra ou promessa que se sabe mentirosa (BENVENISTE, 1995, p. 171).

Nesse sentido, o acréscimo de um hórkos pressuporia que aquele que jura não manterá sua palavra. O termo, então, "revela que facilmente se recorria a um hórkos para apoiar uma promessa que não se pretendia cumprir ou uma afirmação que se sabia falsa" (BENVENISTE, 1995, p. 172). Além disso, tendo em vista a possiblidade de descumprir a regra, o linguista afirma que o juramento militar grego, por exemplo, trazia consigo uma série de imprecações, com a invocação de calamidades, destruição, doenças e nascimento de monstros entre os humanos e os animais. A essa observação, Benveniste acrescenta que há exemplos em outras civilizações em que "as operações simbólicas efetuadas como imprecação no momento do juramento antecipam e garantem magicamente o destino que é prometido ao perjuro" (BENVENISTE, 1947, p. 92).

A possibilidade de transgredir o juramento também está presente no latim sacramentum, derivado do verbo sacrare (declarar sacer, "consagrado aos deuses e excluído do mundo dos homens - espontaneamente ou não" (AGAMBEN, 2011, p. 38)). O sacramentum é o fato ou o objeto por meio do qual se anatemiza sua própria pessoa ou penhor dado. A partir da pronúncia correta da fórmula, a pessoa está potencialmente em estado de sacer, que se efetiva e chama a vingança divina em caso de transgressão da promessa feita. O significado dessa palavra fica mais elucidade ao relacioná-la com iurare: o sacramento é a consagração aos deuses, ao passo em que iurare é simplesmente a repetição 
da fórmula pronunciada no rito.

Por sua vez, o verbo iurare chama a atenção do linguista por sua semelhança com ius, cujo sentido é "direito". Nesse caso, embora haja semelhança formal entre dois vocábulos, os sentidos, em um exame inicial, não se relacionam. Recorrendo ao iraniano e ao védico para explorar a pré-história do latim ius, Benveniste explica que a palavra admite dois sentidos: um relacionado à ideia de conformidade às regras e o outro, à de fórmula que prescreve aquilo a que se deve conformar. A noção de direito em Roma se sustenta nesses dois sentidos.

Assim, ius não se trata de um conceito abstrato, mas sim de uma fórmula. Termos como ius e iura, em seu sentido estrito, indicam "a noção de textos fixados, de fórmulas estabelecidas, cuja posse é privilégio de certos indivíduos, certas famílias, certas corporações" (BENVENISTE, 1995, p. 116). Isso mostra que o que está na base do direito não é o fazer, mas sim o ato de pronunciar, enunciar.

Resta, portanto, esclarecer o sentido do verbo iurare e, cotejando-o com o de ius, verificar se a explicação para ambos os vocábulos é válida. Retoma-se o contexto da enunciação: para se prestar juramento em Roma, havia um iniciador que enunciava um texto que deveria ser repetido pela pessoa que jura, ao mesmo tempo em que esta tocava um objeto sagrado. Assim, "iurare não designa aquilo que entendemos por 'jurar', isto é, o fato de se empenhar de maneira solene sob a invocação de uma divindade [...], é o fato de repetir a fórmula pronunciada" (BENVENISTE, 1995, p. 119-120). O latim reserva a palavra sacramentum para se referir ao fato de se consagrar aos deuses e iurare, portanto, à ideia de pronunciar o ius, o que deve ser feito da maneira exata conforme pronunciado pela pessoa precedente.

Em relação à presença nos deuses no juramento, constatamos a ocorrência desse fenômeno tanto no mundo grego quanto no romano. Os gregos invocavam os deuses não só para conhecer, mas para ver o juramento, colocando-se como testemunhas deste. Os romanos, por sua vez, clamavam que os deuses escutassem a enunciação das fórmulas solenes. Comum às duas sociedades, temos a participação dos deuses nesse momento. A razão deve-se ao fato de que:

\footnotetext{
O castigo pelo perjúrio não é um assunto humano. [...] Supõe-se que o castigo venha dos deuses, por serem eles os garantes do juramento. O perjúrio constitui um delito contra os deuses. E se comprometer com um juramento é sempre se expor de antemão à vingança divina, visto que se implora que os deuses "vejam" ou "ouçam", que estejam em todo caso presentes ao ato de comprometimento. (BENVENISTE, 1995, p. 176).
}

Para Benveniste, a presença das imprecações, bem como a invocação dos deuses nas diferentes formas de juramento sinalizam a possibilidade de que a pessoa que jura pode vir a não cumprir a palavra empenhada. Ou seja, a própria fórmula do juramento já prevê que a pessoa possa perjurar, ou seja, descumprir o juramento. Visto que não se pode garantir o cumprimento daquilo que foi jurado, procuram-se formas de castigar aquele que não fizer suas ações corresponderem ao que foi enunciado, na esperança de que isso possa dissuadi-lo de perjurar. 


\section{Agamben: para além do juramento}

Com a sua arqueologia do juramento, Agamben possibilita um olhar que não se esgota nessa questão específica, mas que se estende para aspectos essenciais da obra de Benveniste. De fato, se considerarmos apenas esse recorte, constatamos que o filósofo faz algumas críticas específicas à exposição de Benveniste sobre o juramento, as quais explicaremos a seguir.

A primeira crítica se localiza no recurso a uma suposta origem religiosa para a motivação do juramento. Agamben explica que isso provém de uma perspectiva, bastante presente nas ciências humanas, "segundo a qual explicar um instituto histórico significa necessariamente reconduzi-lo a uma origem a um contexto sagrado ou mágico-religioso" (2011, p. 20). Especificamente em relação ao tema aqui exposto, a saber, o juramento, o filósofo afirma que a diferenciação entre o que é do jurídico e o que é do religioso está mal colocado: "não só não temos motivos para postular uma fase pré-jurídica na qual ele pertenceria apenas à esfera religiosa, mas talvez deva ser revista toda a nossa maneira habitual de representarmos a relação cronológica e conceitual entre direito e religião" (AGAMBEN, 2011, p. 27). Além disso, ele propõe que "o juramento representa, justamente, o limiar através do qual a linguagem entra no direito e na religio" (2011, p. 37).

As outras críticas referem-se à presença dos deuses e da maldição no juramento. Agamben sintetiza a fórmula do juramento da seguinte maneira: "o juramento parece, portanto, resultar da conjunção de três elementos: uma afirmação, a invocação dos deuses como testemunhas e uma maldição dirigida para o perjúrio" (2011, p. 40). Contrariando essa aparente simplicidade, o autor detém-se precisamente na presença dos deuses e da maldição.

Em primeiro lugar, a natureza do testemunho dos deuses no juramento não é dada em um sentido técnico e não diz respeito à verificação factual do evento, mas ao poder significante da linguagem, na medida que o nome de Deus representa a plena adequação entre a palavra e o ser. Em segundo lugar, Agamben assevera, contra as explicações tradicionais, que a função da maldição no juramento não é invocação aos deuses para punir o perjúrio, propondo, de maneira inversa, que a maldição mostra a ruptura da justa relação constatada anteriormente entre as palavras e as coisas.

A proximidade entre a maldição e a blasfemia leva Agamben a Benveniste, e o mesmo raciocínio utilizado para a explicação anterior serve também para discutir a motivação da blasfemia ${ }^{16}$ proposta pelo linguista. Para o filósofo, não haveria necessidade de recorrer a aspectos externos à linguagem e invocar a interdição sobre o nome de Deus. Agamben esclarece que se trata de uma questão estritamente linguística: o nome de Deus é o melhor, ou único, exemplo em que a palavra corresponde à coisa, visto que "ele [Deus] é o próprio evento de linguagem no qual palavra e coisas se conectam indissoluvelmente" (AGAMBEN, 2011, p. 56, grifos do autor). Nas suas palavras,

\footnotetext{
${ }^{16}$ Chamamos a atenção para o fato de que, na tradução presente na publicação brasileira de “O sacramento da linguagem", a palavra blasfemia encontra-se grafada como "blasfêmia", o que constitui um problema terminológico, como explicamos anteriormente.
} 
A blasfêmia (sic) é um juramento no qual o nome de Deus é tirado do contexto assertório ou promissório, e é proferido em si, no vazio, independente de um conteúdo semântico. O nome, que no juramento expressava e garantia a conexão entre palavras e coisas, e que define a veridicidade e a força do logos, na blasfemia expressa a ruptura desse nexo e o fato de ser vã a linguagem humana. [...] juramento e blasfemia, como bem-dição e mal-dição, cooriginariamente, estão implícitos no mesmo evento de linguagem" (AGAMBEN, 2011, p. 50, grifos do autor).

Assim, a presença de uma maldição no juramento se justifica porque tal fenômeno mostra que não há correspondência entre as palavras e as coisas. Rompido o elo entre a linguagem e o mundo, "o nome de Deus, que expressava e garantia essa conexão 'bemdizente', torna-se o nome da 'mal-dição', a saber, de uma palavra que rompe a sua relação verídica com as coisas" (AGAMBEN, 2011, p. 52).

Na medida que o nome de Deus é experiência da plena adequação entre as palavras e as coisas, em que nomear é realizar a existência de algo, compreende-se que o juramento também é o fenômeno em que se vivencia a língua toda como um nome próprio. Aqui, entra o caráter performativo da linguagem, que suspende o caráter denotativo em favor de colocarse a si mesma como o fato decisivo (ou seja, a autorreferencialidade ${ }^{17}$ ). De acordo com o filósofo, "o que chamamos hoje de performativo em sentido restrito [...] é, na linguagem, a relíquia dessa experiência constitutiva da palavra que se esgota com sua pronúncia, porque o sujeito locutor não preexiste nem se vincula sucessivamente a ela, mas coincide integralmente com o ato de palavra" (AGAMBEN, 2011, p. 68).

Por isso, explica-se também a mudança de significado de blasfemia da vã pronúncia do nome de Deus a um insulto, ou seja, a falar mal da divindade. Para Agamben (2011, p. 51), "à medida que se perde a consciência da eficácia da pronúncia do nome divino, a forma originária da blasfêmia, que consiste em proferi-lo em vão, passa a ser secundária em relação ao proferimento de injúrias ou falsidades sobre Deus".

Apesar dessas críticas, é a Benveniste que Agamben recorre para finalizar seu raciocínio sobre o potencial significante da palavra no seio sociedade, mostrando que compreende a totalidade da reflexão benvenistiana. O filósofo parte de Benveniste para elaborar o seguinte argumento:

[...] o elemento decisivo que confere à linguagem humana as suas virtudes peculiares não reside no instrumento em si mesmo, mas sim no lugar que ele confere ao ser que fala, enquanto disponibiliza dentro de si uma forma de vazio que o locutor toda vez deve assumir para falar. Por outras palavras, na relação ética que se estabelece entre ser falante e a sua língua. O homem é o ser vivo que, para falar, deve dizer 'eu', ou seja, deve 'tomar a palavra', assumi-la e torná-la própria (AGAMBEN, 2011, p. 82).

Em outras palavras, a particularidade do ser humano em relação aos animais não está apenas no fato de que o primeiro é dotado de linguagem, mas em uma característica muito específica dessa capacidade. Trata-se do pronome eu, que permite que todos os falantes

\footnotetext{
${ }^{17}$ Para um exame detalhado desse fenômeno na obra de Benveniste, indicamos ao leitor o capítulo 2 de Flores (2019).
} 
possam se referir a si próprios pela língua através de uma única forma. Para que possamos nos constituir enquanto sujeitos, necessitamos nos apropriar da língua através de um ato individual de utilização, ato que é garantido pela própria estrutura linguística, que dispõe dos pronomes pessoais e assegura a subjetivação. É Agamben, porém, que aponta para uma consequência fundamental disso: apropriar-se da língua e falar "eu" implica aquele que fala no seu discurso.

Juntamente de todo ato de conversão da língua em discurso, surge um alocutário, que é instaurado pelo locutor. Falar é sempre falar para alguém, para um outro que, por sua vez, torna-se locutor quando se apropria da língua e se propõe como "eu" no discurso. Dessa forma, está fundada a dimensão intersubjetiva e social da enunciação, baseada nas relações entre locutor e alocutário construídas por meio da enunciação.

Na estruturação dessas relações interpessoais, temos a evidência de que falar nunca é um ato neutro. De acordo com Dessons (2006), os atos performativos colocam em relevância a dimensão pragmática que subjaz a todo ato de fala: "o cárater pragmático da linguagem constitui a sua natureza política, no sentido de que falar nunca é um processo neutro, mas um ato que implica uma estruturação das relações interpessoais"18 (DESSONS, 2006, p. 48). Assim, fenômenos como a blasfemia e o juramento colocam em relevo a dimensão ética e política do exercício da linguagem enquanto atividade intersubjetiva.

Para Agamben (2011), isso pode ser verificado no juramento, que seria um vestígio, na língua, de uma experiência de linguagem em que falar é fazer, em que há uma adequação plena entre a palavra e o mundo. Para ele, o juramento encontra-se precisamente no cruzamento da língua e da política, servindo como um operador por meio do qual o ser vivo se descobriu falante e decidiu responder por suas palavras.

Portanto, não é suficiente ao ser humano ser dotado da linguagem, pois é necessário enunciar para assumir-se enquanto sujeito e, no mesmo ato, tornar-se responsável por aquilo que fala. Ao descobrir-se falante, o homem sentiu a necessidade de garantir a veracidade da palavra sua e do outro. A experiência performativa da linguagem vivenciada no juramento e a possibilidade de desfazê-la, também presente no juramento por meio da maldição, teriam dado origem à religião e ao direito, de forma que essas instituições, através de mecanismos e dispositivos específicos, pudessem garantir a verdade daquilo que é enunciado.

\section{Considerações finais}

Recuperar a experiência de linguagem em fenômenos como a blasfemia e o juramento equivale a pensar em outras formas de usar a linguagem, ou seja, outras atividades significantes que o homem performa por meio da língua. O verbo performar, nesse caso, não é uma escolha aleatória: trata-se justamente de ressaltar o caráter performativo, de acordo com o qual a linguagem realiza algo no mundo, em detrimento do caráter denotativo ao qual

\footnotetext{
18 Do original: "le caractère pragmatique du langage en constitue la nature politique, au sens où parler n'est jamais un procès neutre, mais un acte qui implique une structuration des relations interpersonnelles".
} 
fomos acostumados. Deparamo-nos, assim, com outros modos de vivenciar a linguagem, o que deixa entrever que a forma como hoje a vivenciamos é, em si mesma, uma construção de um determinado momento. Como diz Agamben (2011, p. 65), “[...] a distinção entre sentido e denotação, que talvez não seja, como estamos acostumados a pensar, um caráter original e eterno da língua humana, mas uma produção histórica".

Nessa empreitada, são as reflexões de Benveniste sobre um assunto restrito que abrem espaço para outras problemáticas contemporâneas, como discurso de ódio, eufemismos e linguagem politicamente correta (cf. STUMPF, 2017). A própria questão da blasfêmia, que parece restrita e até mesmo arcaica em democracias modernas, continua ainda a provocar debates intensos, como comprovam o furor que se seguiu à publicação de Versos Satânicos, de Salman Rushdie, em 1988 e, mais recentemente, à publicação de charges com conteúdo ofensivo a muçulmanos em um jornal dinamarquês (2005). Mais do que furor, temos ainda o caso dos ataques ao jornal francês Charlie Hebdo em 2015, que se seguiram à constante exibição de material satírico sobre o islamismo (inclusive no próprio dia do atentado). Cabe lembrar que, ainda que leis antigas sobre blasfêmia tenham desaparecido ou não sejam atualmente utilizadas quando presentes nos códigos, a discriminação contra crenças religiosas ainda permanece em leis de diversos países. Na impossibilidade de um estado laico julgar ofensas a uma divindade religiosa, fala-se então de linguagem que pode ser considerada ofensiva ao que um grupo de pessoas considera sagrado ou a indivíduos em posições vulneráveis por conta de suas crenças religiosas (VROOM, 2011, LEIRVIK, 2011, BURRIDGE, 2006).

Falar de um sujeito constituído na e pela linguagem, no exercício da fala e da troca entre "eu" e "tu", implica, inevitavelmente, que se discuta a dimensão ética e política que une o homem e sua linguagem. Temos, assim, mais um indício da potência e da atualidade do pensamento benvenistiano, que se expandem ao dialogar com as reflexões de Giorgio Agamben e nos auxiliam a enfrentar modos de estar na língua que a linguística não pode negligenciar.

\section{Referências}

AGAMBEN, Giorgio. O sacramento da linguagem: uma arqueologia do juramento. Belo Horizonte: Editora da UFMG, 2011.

BENVENISTE, Émile. L'expression du serment dans la Grèce ancienne. Revue de L'histoire Des Religions, v. 134, n. 1, p. 81-94, jan. 1947. https://doi.org/10.3406/rhr.1947.5601

BENVENISTE, Émile. Problemas de linguística geral I. 5. ed. Campinas: Pontes, 2005.

BENVENISTE, Émile. Problemas de linguística geral II. 2. ed. Campinas: Pontes, 2006.

BENVENISTE, Émile. Vocabulário das instituições indo-europeias. Volume II: Poder, Direito, Religião. Campinas: Editora da UNICAMP, 1995.

BURRIDGE, Kathryn. Taboo, euphemism, and political correctness. In: BROWN, Keith (ed.). Encyclopedia of Language \& Linguistics. Amsterdam: Elsevier, 2006. p. 455-462. 


\section{https://doi.org/10.1016/B0-08-044854-2/01092-0}

CASTRO, Edgardo. Introdução a Giorgio Agamben: uma arqueologia da potência. Belo Horizonte: Autêntica Editora, 2013.

DESSONS, Gérard. Émile Benveniste: I'invention du discours. Paris: Éditions In Press, 2006.

FLORES, Valdir do Nascimento. Problemas gerais de linguística. São Paulo: Editora Vozes, 2019.

FREUD, Sigmund. Totem e tabu. Porto Alegre. L\&PM Editores, 2013.

LEIRVIK, O. Blasphemy, offense and hate speech: response to Henk Vroom. In: CONFERENCE OF THE EUROPEAN SOCIETY FOR PHILOSOPHY OF RELIGION, 2010, Oxford. Proceedings of the 2010 Conference of the European Society for Philosophy of Religion. Utrecht: Ars Disputandi, 2011. p. 95 - 106. Disponível em: https://dspace.library.uu.nl/handle/1874/294112. Acesso em: 10 dez. 2019.

LESAFFRE, Hubert. En France, le blasphème n'existe plus. Libération. Paris. 18 set. 2012. Disponível em: http://www.liberation.fr/monde/2012/09/18/en-france-le-blaspheme-nexiste-plus 847187. Acesso em: 16 jan. 2015.

LEVELEUX-TEIXEIRA, Corinne. Injure à Dieu, outrage au roi. Le blasphème à la fin du Moyen Age et au début de l'époque moderne: un crime limite. In: DESMONS, Eric; PAVEAU, MarieAnne. Outrages, insultes, blasphèmes et injures: violences du langage et polices du discours. Paris: L'Harmattan, 2008. p. 31-52.

LEVY, Leonard. Blasphemy: verbal offense against the Sacred, from Moses to Salman Rushdie. Chapel Hill, Londres: The University of North Carolina Press, 1993.

NASH, David. Blasphemy in the Christian world: a history. Oxford: Oxford University Press, 2007.

ONO, Aya. "Le nom c'est l'être ": les notes préparatoires d'Émile Benveniste à l'article « La blasphémie et l'euphémie ". Genesis, n. 53, p. 77-86, 2012. https://doi.org/10.4000/genesis.1047

ORSI, Vivian. Tabu e preconceito linguístico. ReVEL, v. 9, n. 17, p. 334-348, 2011.

PRETI, Dino. A linguagem proibida: um estudo sobre a linguagem erótica. São Paulo: T. A. Queiroz, 1983.

STUMPF, Elisa Marchioro. No limite do diálogo: eufemismo e enunciação em Émile Benveniste. 2017. 118 f. Tese (Doutorado em Estudos da Linguagem) - Instituto de Letras, Programa de Pós-Graduação em Letras, Universidade Federal do Rio Grande do Sul, Porto Alegre, 2017.

VROOM, Henk. On blasphemy: an analysis. In: CONFERENCE OF THE EUROPEAN SOCIETY FOR PHILOSOPHY OF RELIGION, 2010, Oxford. Proceedings of the 2010 Conference of the European Society for Philosophy of Religion. Utrecht: Ars Disputandi, 2011. p. 75 - 94. Disponível em: <https://dspace.library.uu.nl/handle/1874/294112>. Acesso em: $10 \mathrm{dez} .2019$. 